\title{
Ultrasound-guided fine-needle aspiration of thyroid nodules: assessment of the ideal number of punctures*
}

\author{
Punção aspirativa com agulha fina guiada pelo ultrassom em nódulos de tireoide: avaliação do número ideal \\ de punções
}

\author{
Sandro Ceratti ${ }^{1}$, Paula Giannini ${ }^{2}$, Ricardo Antenor de Souza e Souza ${ }^{3}$, Orlando Fermozelli \\ Rodrigues Junior ${ }^{4}$
}

\begin{abstract}
Objective: To determine the number of punctures in fine-needle aspiration biopsies required for a safe cytological analysis of thyroid nodules. Materials and Methods: Cross-sectional study with focus on diagnosis. The study population included 94 patients. Results: The mean age of the patients participating in the study was 52 years (standard-deviation = 13.7) and $90.4 \%$ of them were women. Considering each puncture as an independent event, the first puncture has showed conclusive results in $78.7 \%$ of cases, the second, in $81.6 \%$, and the third, in $71.8 \%$ of cases. With a view to the increasing chance of a conclusive diagnosis at each new puncture, two punctures have showed conclusive results in $89.5 \%$ of cases, and three punctures, in $90.6 \%$ of cases with at least one conclusive result. Conclusion: Two punctures in fine-needle aspiration biopsies of thyroid nodules have lead to diagnosis in $89.5 \%$ of cases in the study sample, suggesting that there is no need for multiple punctures to safely obtain the diagnosis of thyroid nodules.
\end{abstract}

Keywords: Thyroid nodules; Fine-needle aspiration biopsy; Ultrasonography-guided fine-needle aspiration.

Resumo Objetivo: Determinar o número de punções aspirativas necessárias para o diagnóstico citológico de nódulos tireoidianos com segurança. Materiais e Métodos: Estudo transversal com enfoque diagnóstico. A amostra foi composta por 94 pacientes. Resultados: A idade média dos participantes do estudo foi de 52 anos (desvio-padrão = 13,7), dos quais $90,4 \%$ eram do sexo feminino. Considerando cada punção como um evento independente, a primeira punção apresentou resultado conclusivo em $78,7 \%$ dos casos, a segunda punção mostrou resultado conclusivo em $81,6 \%$ dos casos e a terceira punção mostrou resultado conclusivo em $78,1 \%$ dos casos. Considerando-se a chance de se obter o diagnóstico conclusivo a cada nova punção, tem-se que com duas punções obteve-se 89,5\% de resultados conclusivos e com três punções, 90,6\% apresentaram pelo menos um resultado conclusivo. Analisando-se todos os resultados obtidos, identificaram-se 70,2\% de nódulos benignos, 5,3\% de nódulos malignos, 17,0\% de resultados indeterminados e 7,4\% de amostras não diagnósticas. Conclusão: Duas punções permitiram a realização do diagnóstico de nódulos de tireoide em $89,5 \%$ dos casos, na amostra estudada, sugerindo que não há necessidade de múltiplas punções para se obter o diagnóstico de nódulos tireoidianos com segurança.

Unitermos: Nódulo de tireoide; Punção aspirativa por agulha fina; Punção aspirativa guiada por ultrassom.

Ceratti S, Giannini P, Souza RAS, Rodrigues Jr OF. Ultrasound-guided fine-needle aspiration of thyroid nodules: assessment of the ideal number of punctures. Radiol Bras. 2012 Mai/Jun;45(3):145-148.

\section{INTRODUCTION}

Thyroid nodules represent a frequent clinical problem characterized by small lesions in the thyroid gland that radiologi-

* Study developed at Rad Med Radiologia e Serviços Médicos, São Roque, SP, at Hospital Beneficência Portuguesa de São Paulo, São Paulo, SP, and at Instituto de Patologia e Citologia, Sorocaba, SP, Brazil.

1. MD, Specialist in Radiology and Imaging Diagnosis, Physician Assistant at Conjunto Hospitalar de Sorocaba and Specialization in Radiology at Pontifícia Universidade Católica de São Paulo (PUC-SP), Sorocaba, SP, Brazil.

2. MD, Resident of Radiology at Med Imagem - Hospital Beneficência Portuguesa de São Paulo, São Paulo, SP, Brazil.

3. MD, Pathologist at Centro Integrado de Patologia - Hospital Beneficência Portuguesa de São Paulo, São Paulo, SP, Brazil.

4. MD, Pathologist, Professor, Division of Pathology at Pontifícia Universidade Católica de São Paulo (PUC-SP), Sorocaba, SP, Brazil. cally are distinct from the thyroid parenchyma $^{(\mathbf{1})}$. Epidemiological studies demonstrate a prevalence of palpable nodules in $4 \%$ to $7 \%$ of the general population ${ }^{(2,3)}$ and such frequency increases to $30 \%$ to $50 \%$ with the utilization of ultrasonography ${ }^{(\mathbf{4})}$. The dissemination of the utilization of imaging diagnosis methods has increased the frequency of incidentally diagnosed thyroid nodules. Such nodules are identified at carotid ultrasonography, computed to-

Mailing Address: Dr. Sandro Ceratti. Rad Med Radiologia e Serviços Médicos. Rua Santana, 142, Vila Marques. São Roque, SP, Brazil, 18130-555. E-mail: sanceratti@gmail.com

Received November 22, 2011. Accepted after revision May 7, 2012. mography and other methods not related to the thyroid, and lead to the diagnosis of nodules whose further evaluation is required $^{(5)}$. Carcinomas many times smaller than $1 \mathrm{~cm}$ in diameter have increasingly been more frequently found ${ }^{(\mathbf{6})}$, a fact which, in the last decades, has improved the prognosis in patients with malignant thyroid nodules.

The assessment of thyroid nodules was improved in the 1980's with the development of fine-needle aspiration biopsies (FNAB), which is the most accurate method and with the best cost-benefit ratio for the assessment of thyroid nodules and differentiation between malignant and 
benign disease ${ }^{(\mathbf{1 , 5 - 8})}$. FNAB has a low complication risk and is the procedure of choice in the evaluation of thyroid nodules, and has led to a significant reduction in the number of patients submitted to surgery $^{(\mathbf{1 , 5})}$.

The incidence of malignant thyroid nodules in patients with one or more nodules and without other risk factors ranges from $6 \%$ to $13 \%{ }^{(9-11)}$. FNAB provides diagnostic information in $85 \%$ of patients with accuracy $>95 \%{ }^{(\mathbf{1 2})}$. Results from FNAB are classified into four categories as follows: benign, malignant, suspicious for malignancy or undetermined (follicular neoplasia or Hurthle cell neoplasm) and non diagnostic ${ }^{(6)}$.

The most common thyroid lesion is the benign colloid nodule, followed by nodular goiter, hyperplastic nodules, plain cysts, subacute thyroiditis and lymphocytic thyroiditis $^{(\mathbf{5})}$. The undetermined category or follicular lesion is the most challenging diagnostic category, as it comprises two clinically different groups of lesions, namely, benign follicular lesions (follicular lesions, follicular adenomas, Hurthle cell adenomas and hyperplasia of non neoplastic follicular cells) and malignant follicular lesions (follicular carcinoma, a variation of papilliferous carcinoma and Hurthle cells carcinoma) ${ }^{(\mathbf{5})}$.

Ultrasound-guided FNAB is a simple procedure which requires few apparatuses and can be performed on an outpatient basis. The patient is placed in supine position with hyperextension of the neck. The cervical region is cleaned with alcohol and generally local anesthesia is not required. The aspirate is collected with a $30 \times 7$ gauge needle attached to a $10 \mathrm{ml}$ syringe. The needle is quickly inserted into and drawn out of the nodule until a small amount of fluid or blood is seen at the base of the needle. It is recommended that two to three punctures be performed on different areas of the nodule, if possible. The aspirate is distributed on 2-6 glass slides and each slide is covered to prepare 4 to 12 specimens $^{(\mathbf{5})}$.

The non diagnosis of thyroid nodules by FNAB may be caused by insufficient aspiration of cytological material or hemorrhagic specimen ${ }^{(5)}$. Despite the wide utilization of ultrasound-guided FNAB, few studies have evaluated the impact of such technique on diagnosis results ${ }^{(\mathbf{7}, 13)}$.

Although posing low risk for complications, particularly involving pain, discomfort and development of small hematomas, other more severe complications may be observed. The literature review has shown that there are reports of hemorrhage, hematomas, edema, infection, laryngeal nerve palsy, vasovagal reaction, tracheal perforation, dysphagia, tumor dissemination (the needle can induce seeding of malignant cells) and changes in nodule volume ${ }^{(\mathbf{1 4})}$. Considering that complications are rare, although they may occur, the lower the number of punctures, the lower is the complication risk.

The number of punctures required for the diagnosis of thyroid nodules is not well established in the literature. Identifying the number of required punctures for a safe diagnosis of thyroid nodules will contribute to the improvement of the technique and will possibly reduce the number of punctures, the discomfort and the risk for complications. Thus the present study is aimed at determining the necessary number of aspiration punctures for a safe cytological diagnosis of thyroid nodules.

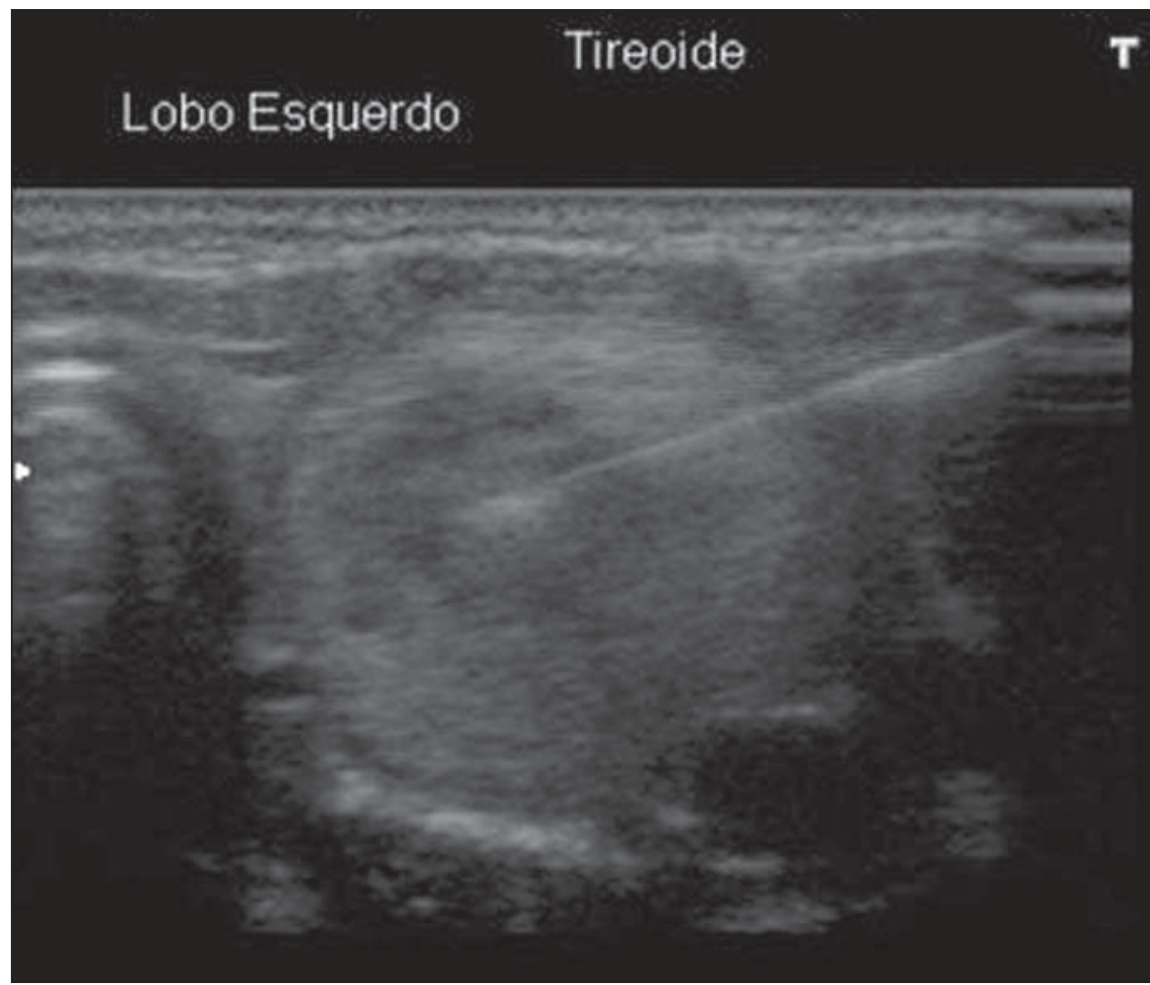

Figure 1. Thyroid nodule aspiration puncture - papilliferous carcinoma.

\section{MATERIALS AND METHODS}

Cross sectional study with emphasis on diagnosis. The study population included patients submitted to ultrasound-guided FNAB for the diagnosis of thyroid nodules. The sample comprised 94 patients who underwent the examination in the period between May 2009 and December 2010 in a private clinic of imaging diagnosis. The ultrasound-guided FNABs were performed by a single team including a radiologist and a nursing technician.

The technique utilized in the procedures was aspiration puncture with a $30 \times 7$ gauge needle attached to a $10 \mathrm{ml}$ syringe and being advanced into various positions in the nodule and moved to and fro without suction. All the patients received local anesthesia with lidocaine (Xylocaine) 1\% without vasoconstrictor before the procedure. Between one and five punctures were performed in the same nodule and the material was sent for cytological analysis in separate vials, labeled as specimens 1, 2 and 3 , which contained varied number of prefixed slides. The specimens were analyzed by two pathological anatomy laboratories identified as laboratory 1 and labo- 
ratory 2 , with the specimens being sent to either laboratory according to patients' health insurance coverage. All specimens had the results presented on independent reports. The specimens were also classified according to their appropriateness as satisfactory, unsatisfactory or limited.

The biopsy results were entered into a databank of the SPSS 13.0. Each case was analyzed with respect to the rate of success in the diagnosis, according to the number of performed punctures. Two approaches were adopted for this analysis, one of them considering each puncture as an independent event and another considering how much each additional puncture would increase the probability of safely reaching the diagnosis.

\section{RESULTS}

The present study analyzed results of oncotic cytology of thyroid nodules of 94 patients with mean age of 52 years (standard-deviation $=13.7$ ), of which $90.4 \%$ were women. All the patients were submitted to at least one thyroid puncture, $76 \mathrm{pa}$ tients were submitted to two punctures, and 64 patients to three punctures. Two patients were submitted to four punctures and one patient, to five punctures. It is important to highlight that the fourth and fifth puncture did not add any further information to that obtained in the previous punctures. The mean number of punctures was 2.5 (standard deviation $=0.9$ ) with the number of punctures ranging between 1 and 5 as previously mentioned.

The analysis of conclusive results according to the number of punctures demonstrated that, considering each puncture as an independent event, the first puncture presented conclusive results in $78.7 \%$ of the cases. Considering the second puncture as an independent event, the result was conclusive in $81.6 \%$ of the cases, and considering the third puncture as an independent event, the result was conclusive in $78.1 \%$ of the cases.

Considering the chance of obtaining the conclusive diagnosis at each new puncture, one observed that for patients who were submitted to two punctures, $89.5 \%$ presented at least one conclusive result. Among the patients who were submitted to three punctures, $90.6 \%$ presented at least one conclusive result, as shown on Table 1.

As regards the thyroid nodules, $70.3 \%$ were benign, $5.3 \%$ were malignant, $17.0 \%$ were undetermined, while $7.4 \%$ of the specimens were non diagnostic because of the scarcity of representative cell elements, scarce epithelial cellularity or for hemorrhagic sample.

The results demonstrated that in the first specimen or first puncture the most frequent diagnosis was adenomatous goiter (23.4\%), followed by non diagnostic specimens $(21.3 \%)$ and follicular pattern nodule $(13.9 \%)$. Papilliferous carcinoma was diagnosed in $5.3 \%$ of the cases diagnosed at first puncture. At the second puncture or second specimen, adenomatous goiter was also predominant $(19.7 \%)$, followed by goiter $(14.1 \%)$ and follicular pattern nodule $(13.1 \%)$. Papilliferous carcinoma was diagnosed in $3.9 \%$ of the second puncture slides. In the analysis of the diagnoses obtained from the third puncture, one has observed that adenomatous goiter $(21.9 \%)$ and non diagnostic specimens $(21.8 \%)$ predominated, followed by follicular pattern nodules $(14.1 \%)$ and goiter $(14.1 \%)$. Papil- liferous carcinoma was identified in $4.7 \%$ of the third puncture slides (Table 2).

\section{DISCUSSION}

FNAB still remains as the main step towards diagnosis of thyroid nodules ${ }^{(8)}$. One of the main advantages of FNAB lies on the fact that such diagnostic method provides a reliable interpretation of thyroid nodules and many times avoids unnecessary surgeries. However, in order to avoid surgery, appropriate cytological material must be obtained by FNAB. Non diagnostic specimens are related to failure in puncture technique (operator error), very small nodules, mixed lesions (cystic/solid contents), fibrotic nodules or insufficient number of cells in the specimen $^{(8)}$.

The most common cause for non diagnostic specimens is the failure in aspirating a sufficient number of cells for diagnosis, which occurs in $1 \%$ to $15 \%$ of the punctures $^{(\mathbf{1 3})}$. In the present study, the total rate of non diagnostic specimens was $7.4 \%$, a finding similar to those reported by other authors, who found non diagnostic or inconclusive specimen rates between $3 \%$ and

Table 1 Number of conclusive results according to the number of punctures.

\begin{tabular}{ccccc}
\hline $\begin{array}{c}\text { Number } \\
\text { of punctures }\end{array}$ & $\begin{array}{c}\text { Total number } \\
\text { of patients }\end{array}$ & $\begin{array}{c}\text { Total number } \\
\text { of diagnostic punctures }\end{array}$ & $\%$ & Cl 95\% \\
\hline 1 & 94 & 74 & 78.7 & $77.4-82.1$ \\
2 & 76 & 68 & 89.5 & $87.2-91.7$ \\
3 & 64 & 58 & 90.6 & $88.4-92.8$ \\
\hline
\end{tabular}

Cl, confidence interval.

Table 2 Distribution of diagnosis according to the number of punctures.

\begin{tabular}{cccc}
\hline Diagnosis & $\begin{array}{c}\text { Puncture } 1(\%) \\
n=94\end{array}$ & $\begin{array}{c}\text { Puncture 2 (\%) } \\
n=76\end{array}$ & $\begin{array}{c}\text { Puncture } 3(\%) \\
n=64\end{array}$ \\
\hline Follicular pattern nodule & 13.9 & 13.1 & 14.1 \\
Goiter (hyperplastic process) & 7.4 & 14.6 & 14.1 \\
Colloid goiter & 8.5 & 6.6 & 3.1 \\
Adenomatous goiter & 23.4 & 19.7 & 21.9 \\
Lymphocytic thyroiditis & 6.4 & 7.9 & 7.8 \\
Cyst & 1.1 & - & - \\
Negative for malignancy & 7.4 & 6.6 & 7.8 \\
Papilliferous carcinoma & 5.3 & 3.9 & 4.7 \\
Non diagnostic & 21.3 & 18.4 & 21.8 \\
Cystic lesion & 2.1 & 2.7 & 1,6 \\
Hemorrhagic smears & 1.1 & 1.3 & - \\
Cystic degeneration & 1.1 & 1.3 & - \\
Follicular lesion & 1.0 & 3.9 & 3.1 \\
\hline
\end{tabular}


$11 \%$ of their specimens ${ }^{(\mathbf{1 3 , 1 5 , 1 6 )}}$. On average, the number of punctures in the present study was 2.5 punctures per patient, ranging from 1 to 5 punctures, a lower number than that of a study which reported an average of 3.8 punctures, ranging from 1 to 11 punctures per patient ${ }^{(13)}$.

In the present study, the authors observed that the performance of a second puncture increased the probability of reaching a conclusive result by $10.8 \%$. On the other hand, the performance of the third puncture increased such probability by only $1.1 \%$. Therefore, it is concluded that in most of cases two punctures were sufficient to obtain a conclusive diagnosis. The increase in the change of obtaining a conclusive diagnosis with a third puncture was irrelevant.

This is a relevant finding, as the number of punctures in thyroid nodules required to obtain a conclusive diagnosis is not established in the literature. Studies and guidelines on thyroid nodules do not provide recommendations on the number of punctures required for a conclusive diagnosis ${ }^{(\mathbf{1 , 5 - 7 , 1 2})}$. The authors have found only one article which investigated the impact of the technique (number of performed punctures, among others) on the positiveness of the diagnoses ${ }^{(\mathbf{1 3})}$. It is important to highlight, therefore, the practical value of the present study for clinical practice, since it has identified that multiple punctures are not necessary to obtain a conclusive diagnosis. The reduction of the number of punctures is beneficial, as it reduces the exposure to pain, discomfort and the chances of complications associated with punctures.

It is important to remind that among the non diagnostic or inconclusive specimens, the risk for malignancy ranges between $4 \%$ and $20 \%{ }^{(8,17)}$ and in such cases repetition of FNAB is recommended ${ }^{(\mathbf{1})}$.

Also in relation to the technique itself, it is important to remind that there are diagnostic centers that maintain a pathologist in loco during the performance of the punc- tures, who verifies whether the collected specimens are appropriate before they are sent to the laboratory. However, most diagnostic centers do not have such a professional in loco, and the slides with collected specimens are directly sent to the laboratory. In cases of insufficient material, the patient is submitted to new punctures, hence the practical value of the present study.

The prevalence of benign nodules in the present study was $70.6 \%$ while the malignant nodules prevalence was $5.3 \%$, a rate similar to those found by other authors who demonstrated malignancy prevalence between $3 \%$ and $16 \%{ }^{(\mathbf{9 - 1 1 , 1 3 , 1 5 , 1 6 )}}$ and benign nodules between $69 \%$ and $81 \%{ }^{(\mathbf{1 3}, 15,16)}$.

Some limitations in the present study should be pointed out and avoided in future studies. First, the sample size was small and convenient, which limits the generalization of the results. Second, the specimens were analyzed in different laboratories, which might potentially induce biased results. However, it is important to highlight that the objective of the present study was not evaluating the diagnostic accuracy of the laboratories, but only defining the relevance of the number of punctures for proper diagnosis of thyroid nodules.

\section{CONCLUSION}

Two fine needle aspiration punctures allowed appropriate diagnosis of thyroid nodules in $89.5 \%$ of the cases in the present study sample, suggesting that there is no need for multiple punctures to safely obtain the diagnosis of thyroid nodules.

\section{Acknowledgements}

To the nurse Marina de Góes Salvetti, for her assistance in the organization of data and in the text review.

\section{REFERENCES}

1. American Thyroid Association (ATA) Guidelines Taskforce on Thyroid Nodules and Differentiated Thyroid Cancer, Cooper DS, Doherty GM, et al. Revised American Thyroid Association manage- ment guidelines for patients with thyroid nodules and differentiated thyroid cancer. Thyroid. 2009; 19:1167-214.

2. Rojeski MT, Gharib H. Nodular thyroid disease Evaluation and management. N Engl J Med. 1985;313:428-36.

3. [No authors listed]. The thyroid nodule. Ann Intern Med. 1982;96:221-32.

4. Brander A, Viikinkoski P, Nickels J, et al. Thyroid gland: US screening in middle-age women with no previous thyroid disease. Radiology. 1989; 173:507-10.

5. Ogilvie JB, Piatigorsky EJ, Clark OH. Current status of fine needle aspiration for thyroid nodules. Adv Surg. 2006;40:223-38.

6. Maia AL, Ward LS, Carvalho GA, et al. Nódulos de tireóide e câncer diferenciado de tireóide: consenso brasileiro. Arq Bras Endocrinol Metab. 2007;51:867-93.

7. Tublin ME, Martin JA, Rollin LJ, et al. Ultrasound-guided fine-needle aspiration versus fineneedle capillary sampling biopsy of thyroid nodules: does the technique matter? J Ultrasound Med. 2007;26:1697-701

8. Rosen JE, Stone MD. Contemporary diagnostic approach to the thyroid nodule. J Surg Oncol 2006;94:649-61.

9. Nam-Goong IS, Kim HY, Gong G, et al. Ultrasonography-guided fine-needle aspiration of thyroid incidentaloma: correlation with pathological findings. Clin Endocrinol (Oxf). 2004;60:21-8.

10. Kunreuther E, Orcutt J, Benson C, et al. Prevalence and distribution of carcinoma in the uninodular and multinodular goiter. 76th Annual Meeting of the American Thyroid Association. Vancouver, BC, Canada, September 29-October 3, 2004.

11. Camargo RYA, Tomimori EK. Uso da ultra-sonografia no diagnóstico e seguimento do carcinoma bem diferenciado da tireóide. Arq Bras Endocrinol Metab. 2007;51:783-92.

12. Gharib H. Fine-needle aspiration biopsy of thyroid nodules: advantages, limitations, and effect. Mayo Clin Proc. 1994;69:44-9.

13. Redman R, Zalaznick H, Mazzaferri EL, et al. The impact of assessing specimen adequacy and number of needle passes for fine-needle aspiration biopsy of thyroid nodules. Thyroid. 2006;16:5560

14. Polyzos SA, Anastasilakis AD. Clinical complications following thyroid fine-needle biopsy: a systematic review. Clin Endocrinol (Oxf). 2009; 71:157-65.

15. Theoharis CG, Schofield KM, Hammers L, et al The Bethesda thyroid fine-needle aspiration classification system: year 1 at an academic institution. Thyroid. 2009;19:1215-23.

16. Baloch ZW, Sack MJ, Yu GH, et al. Fine-needle aspiration of thyroid: an institutional experience. Thyroid. 1998;8:565-9.

17. Cibas ES, Ali SZ. The Bethesda System for Reporting Thyroid Cytopathology. Thyroid. 2009; 19:1159-65. 